\title{
Development of a reverse transcription droplet digital PCR (RT-ddPCR) assay for sensitive detection of simian immunodeficiency virus (SIV)
}

Samuel Long ${ }^{*}$ and Brian Berkemeier

\begin{abstract}
Background: Simian immunodeficiency virus (SIV)-infected rhesus macaques constitute an excellent model of human HIV infection. Sensitive detection of SIV RNA in cell and tissue samples from infected animals subjected to treatment regimens becomes especially critical in determining which therapeutic attempts are successful, and consequently, which interventions should be prioritized in HIV cure research.

Results: In this report, we describe the design and testing of a Raindance ddPCR platform-based, sensitive SIV reverse transcription droplet digital PCR (RT-ddPCR) assay by exploring the combinations of various priming conditions and reverse transcriptases, and testing one-step vs. two-step procedures, to eliminate background signal(s) and enable detection and quantification of low level target signals.
\end{abstract}

Conclusions: Similar reaction conditions and assay validation procedures can be explored for potential development of additional assays for other applications that require sensitive detection of low-level targets in RNA samples.

Keywords: HIV cure research, SIV, RNA, RT-ddPCR, Raindance, Viral reservoir

\section{Background}

Quantitative reverse transcription PCR (qRT-PCR) has established itself to be the benchmark for RNA target detection and quantification. The technology yields accurate quantitative data, and significantly simplifies quality control and assay standardization. One of the most prevalent applications of qRT-PCR is for the detection of viral loads [1-3], in which qRT-PCR-enabled data on various causative infectious agents [4] have helped to study disease processes and delineate connections between unique viral sequences and clinical signs and symptoms [5]. Various qRT-PCR assays have been developed to detect and quantify negative-strand RNA viruses (including the

*Correspondence: Samuel.Long@nih.gov

AIDS and Cancer Virus Program, Frederick National Laboratory for Cancer Research, Frederick, MD 21702, USA measles and mumps viruses, and various viruses that target the respiratory tract) [6, 7], positive-strand RNA viruses (including rhino-, entero- and coronaviruses such as SARS-CoV-2) [8-10], double-stranded RNA viruses (such as human rotaviruses) [11], and retroviruses (HIV, HTLV, and related viruses in animal models, such as simian immunodeficiency virus (SIV)) [12-16]. In most cases, qRT-PCR assays are more sensitive than traditional methods such as viral culture [17], and have led to a significant increase in the accuracy and clinical relevance of patient testing. Several assays have been critical for identifying, isolating and treating patients and defining the viral epidemiology during some of the recent and ongoing pandemics $[18,19]$.

Despite its tremendous utility, qRT-PCR has several limitations. First, quantitation relies on external reference/standard material, and independent, accurate original author(s) and the source, provide a link to the Creative Commons licence, and indicate if changes were made. The images or other third party material in this article are included in the article's Creative Commons licence, unless indicated otherwise in a credit line to the material. If material is not included in the article's Creative Commons licence and your intended use is not permitted by statutory regulation or exceeds the permitted use, you will need to obtain permission directly from the copyright holder. To view a copy of this licence, visit http://creativecommons.org/licenses/by/4.0/. The Creative Commons Public Domain Dedication waiver (http://creativeco mmons.org/publicdomain/zero/1.0/) applies to the data made available in this article, unless otherwise stated in a credit line to the data. 
determination of the reference/standard is critical to successful quantitation by qRT-PCR. Second, extreme sequence heterogeneity exists in some viruses, which can interfere with primer and/or probe binding to target sequences and consequently lead to under-quantification and even non-recognition of targets with significant sequence divergence such as newly identified subtypes and clades. Template sequence heterogeneity also often limits the design of qRT-PCR assays, which requires placement of primer and probe sequences in highly conserved regions. Third, in some diseases, tissue sites have been found to serve as better predictors of disease outcome and indicators of treatment efficacy [20], highlighting the value of sensitive detection of viruses in tissues from infected individuals or animal models. However, nucleic acid extracted from tissues can present challenges during qRT-PCR quantification due to co-purified inhibitors and significant amounts of background nucleic acid (i.e. compared to nucleic acid extracted from plasma), which can both contribute to quantitation inhibition. Consequently, sensitivity limitations of many tissue qRT-PCR assays derive mainly from how much input nucleic acid is allowed in each reaction before inhibition occurs.

Digital PCR conceptually takes a different approach to measure the number of target nucleic acid molecules in a sample. Instead of relying on PCR threshold cycle (Ct) values and standard curves as in real-time PCR (qPCR), digital PCR partitions reactants in each PCR reaction into up to millions of mini-reactions. These reactions are thermocycled to PCR endpoint, the numbers of positive and negative reactions are scored, and the target copy number in the original sample is calculated based on Poisson statistics. Compared to qPCR, digital PCR allows direct absolute quantitation of analyte without the need for external standards or calibration curves, and is therefore not influenced by inaccuracy during reference/standard quantitation. As digital PCR quantitation relies on detecting end point PCR products, this method is less susceptible than Ct-dependent qRT-PCR to inefficient amplification, which can occur due to primer and/ or probe mismatches caused by sequence heterogeneity, or inhibitors in samples. Additional advantages include higher quantification precision, especially at lower target template copy numbers, as well as greater multiplexing ability because of digital PCR's unique amplitude or ratiobased higher order multiplexing [21]. Digital PCR has also been widely used in virus/pathogen analysis [22, 23], in addition to cancer mutation detection [24-27], GMO screening [28], gene and miRNA expression testing, copy number variation $(\mathrm{CNV})$ determination [29-31], as well as nucleic acid reference standard and NGS library quantification [32].
Traditionally, digital PCR presented two limitations compared to qPCR. (1) Limited dynamic range. In digital PCR, dynamic range by definition is determined by partition number that is available for each sample, as ideally each reaction compartment contains at most one target molecule. On chip- and array-based platforms (i.e. Fluidigm BioMark HD, QuantStudio 3D Digital and JN MedSys Clarity and Clarity Plus) partition number per sample is in the range of 10,000 to 45,000 , while on a couple of oil emulsion droplet digital (i.e. ddPCR) platforms (i.e. Stilla Naica System and BioRad QX100/200 instruments), partition number per sample is on the order of 20,000 to 30,000 . These relatively low partition numbers consequently necessitate dilution of many input samples to achieve accurate measurements [33]. The Raindance ddPCR platform, which is used in the current report, partitions each sample into 10 million droplets (i.e. 6 log dynamic range), making the platform compare favorably to the quantification dynamic range achieved on qPCR systems. (2) Limited nucleic acid input in each reaction. Overloading each reaction with nucleic acids above certain threshold amount in some ddPCR platforms [34] was reported to cause significant droplet deformation, decline of droplet number, and quantitation inhibition (i.e. fewer target-containing droplets reach the required fluorescent intensity at the end of thermocycling). We recently reported [22] that on the Raindance ddPCR platform, at least 8 million mammalian cell equivalent genome can be included in each reaction without causing droplets integrity or numbers to drop. In addition, 4 million mammalian cell equivalent genome was included in each reaction without introducing viral target quantitation inhibition. The Raindance ddPCR platform, therefore, drastically improves the nucleic acid input quantity in each reaction.

Simian immunodeficiency virus (SIV)-infected rhesus macaques constitute an excellent model of human HIV infection [35-41]. Many aspects of infected monkeys such as viral infection, pathogenesis and response to cure strategies closely mirror those of infected humans. Sensitive detection of SIV RNA in cell and tissue samples from infected animals subjected to treatment regimens becomes especially critical in determining which attempts are successful, and consequently, which interventions should be prioritized. In the current report, we describe the development and validation of a SIV RTddPCR assay through exploration of combinations of various priming conditions and reverse transcriptases, and testing one-step vs. two-step procedures. The SIV RT-ddPCR assay described here is able to detect low level (i.e. single digit level) viral nucleic acid [22], making it ideally suited for the detection of rare events (such as in the context of antiretroviral therapy in HIV cure 
studies). Similar reaction conditions and assay validation procedures can be explored for potential development of additional assays for applications that require sensitive detection of low quantity target(s) from RNA samples derived from cell or tissue sources.

\section{Results}

\section{One-step RT-ddPCR}

In the process of developing a ddPCR assay for quantifying SIV RNA, we first tested the option of one-step reverse transcription ddPCR (RT-ddPCR). The "onestep" nomenclature by definition refers to the RT step being performed in the same reaction compartment (i.e. tube, microwell, or droplet) as the PCR step. One-step qRT-PCR has been commonly used in gene quantitation due to advantages such as: (1) Simpler workflow, during which no transfer or procedural manipulation is required once the RT step is initiated, which reduces both risk of contamination and sample-to-sample variability due to reduced number of handling steps. (2) Reduced $3^{\prime}$ and $5^{\prime}$ biases introduced by random oligomers and oligo-dT primers. (3) Single RNA molecules being converted to cDNA without competition and entire cDNA sample being used as template for the PCR step. Both can contribute to enhanced detection sensitivity. (4) Automation potential. The fast and simple procedure allows rapid processing of multiple samples and enables easy automation.

For one-step RT-ddPCR, the SuperScript III One-Step RT-PCR System with Platinum Taq DNA Polymerase was used to perform both the CDNA synthesis and PCR amplification steps. More specifically, the one-step reaction mastermix was combined with the enzyme mix, gene-specific primers, probe(s), test or control RNA sample or reference standard, and droplet stabilizer. The mixture was dropletized, and incubated on a thermocycler with adjustable ramp speed (a slower ramp speed was required for ddPCR as it benefits equilibrating temperature exposure across the droplet population because heat transfers more slowly in emulsified samples than in bulk PCR reaction). The end-point PCR products were then analyzed on the Raindance Sense instrument for droplet counts and fluorescent intensity reading. The data thus generated were in turn analyzed with the RainDrop Analyst software to generate graph and statistical data.

In previous ddPCR tests [22; also see below], assays incorporating minor groove binder (MGB) modified detection probes gave the tightest clusters and clean background in target area (i.e. where positive droplets are located on the plotting space), and were therefore adopted for the PCR stage of the one-step procedure. Four different assay/sample combinations were tested, including SIV assay plus SIV standard spike (Fig. 1a, b),
SIV assay plus SIV standard spiked in Rhesus macaque RNA background (Fig. 1c, d), SIV and CCR5 assays plus SIV standard spike (Fig. 1e, f), and SIV and CCR5 assays plus SIV standard spiked in Rhesus macaque RNA background (Fig. 1g, h). One main issue associated with the one-step procedure was background signals in target region when there was no target input, which prevented the utility of the one-step procedure in quantifying low level viruses.

\section{Two-step RT-ddPCR}

We then tested the two-step RT-ddPCR option. This method separates the RT step and the PCR step in two different reaction vessels. The advantages associated with two-step RT-PCR are: (1) The RT and PCR steps being performed separately, allowing both steps to be optimized to ensure efficient and accurate amplification, i.e. added flexibility regarding choice of primers/priming methods and a wide variety of RT and PCR enzymes. (2) Use of oligo-dT primers or random oligomers for reverse transcription enabling cDNA from a single reverse transcription to be used in several PCRs for analysis of multiple targets, and increased sensitivity for some target templates. (3) Precious RNA samples being transcribed into more stable cDNA without delay for long-term storage and later use.

For two-step RT-ddPCR, a reverse transcriptase combined with a priming method was used to perform the cDNA synthesis step in bulk. The RT enzyme was mixed with other reaction components, including dNTPs, buffer components, random hexamers or gene-specific primer, and test or control RNA sample or reference standard. The mixture was incubated allowing the $\mathrm{RT}$ reaction to complete, and then supplemented with components required for the PCR step (including TaqMan genotyping mastermix, primers and MGB-based probe(s)) and the droplet stabilizer. (For the ddPCR step, we previously compared various probe systems and their combinations with different mastermix conditions. MGB probe assays in TaqMan genotyping mastermix, among all the combinations tested, gave the best result in that the signal cluster was tight, there was no background signal in target signal region for no template controls, and ddPCR reads agreed well with input template quantity [22]) This final mixture was dropletized, and incubated in a thermocycler at a ramp speed of $0.5{ }^{\circ} \mathrm{C} / \mathrm{s}$. The end-point PCR products were then analyzed on the Raindance Sense instruments for droplet counts and fluorescent intensity reading, and data analyzed with the RainDrop Analyst software to generate graphical and statistical data.

We tested different cDNA cocktail combinations involving M-MLV and SSIII as RT enzymes, random 


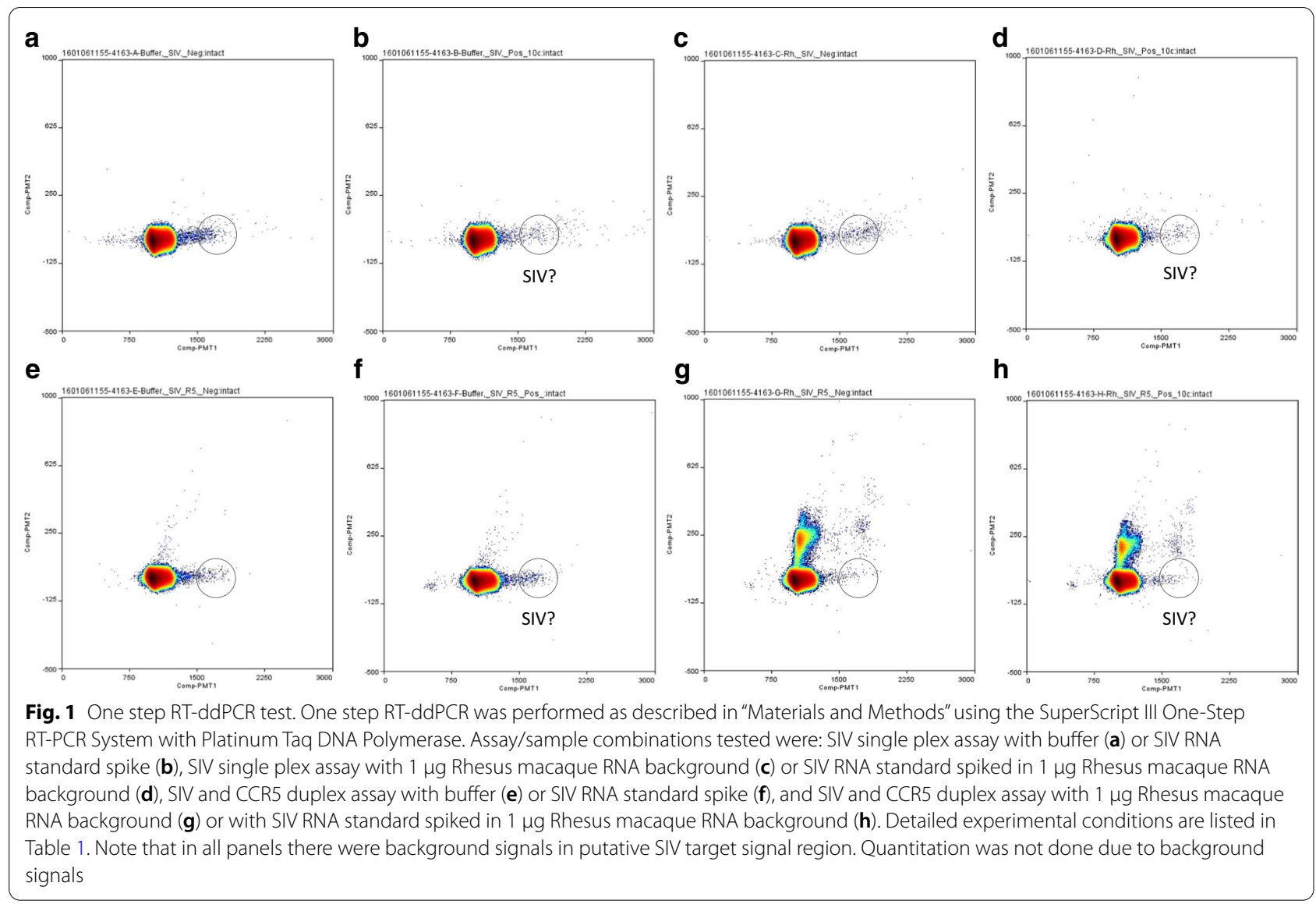

hexamers and sequence specific-primer as priming methods using a low SIV RNA template input range (i.e. 10 copies of SIV RNA standard), with a major emphasis of identifying conditions that would enable detection of low-levels of viral RNA, typical of those encountered in subjects on prolonged cART suppression. We found that 200U M-MLV and gene specific priming performed well as the target signal background was clean, there was distinct target positive signal cluster, and the ddPCR reading agreed with template input (Fig. 2a, b; Additional File 1: Fig. 1 and Table 1). 200U of SSIII in each RT reaction gave a similar ddPCR readout after the PCR step, however, there was a low background in the SIV target signal region of no template control reactions (Fig. 2c, d). Random hexamers, combined with M-MLV or SSIII (200U in each reaction) yielded significantly fewer ddPCR signal counts compared to template input (Fig. 2e-h), with background signals continuing to be an issue when SSIII was used as the RT enzyme. The background signal issue persisted when the quantity of SSIII was reduced to $20 \mathrm{U}$ in each RT reaction, regardless of the priming methods used (Fig. 3).

\section{Superscript IV (SSIV) test}

We proceeded to test another reverse transcriptase, SSIV, in the two-step procedure, as it was previously shown to overcome reaction inhibition from sources such as alcohols, salts, detergents, heparin, hematin, bile salts, formalin, which are typically found in sample preparation reagents, cells and tissues and FFPE samples. This reverse transcriptase can potentially benefit RNA quantification analysis of samples originating from a variety of sources, especially cells and tissues. We showed that SSIV was compatible with the two-step RT-ddPCR protocol and low copy viral signal was successfully identified without background issues when SSIV was used as the reverse transcriptase in the procedure (Fig. 4a, b).

\section{Discussions}

In this report we described the design and testing of a SIV RT-ddPCR assay through testing combinations of different priming conditions, reverse transcriptases, and various procedures, to eliminate background signal(s) and ensure detection and quantification of low-level target signals. We recently reported that the validated assay can detect single digit level SIV RNA in each reaction 
Table 1 RT-ddPCR reaction conditions and quantification results

\begin{tabular}{|c|c|c|c|c|c|c|c|}
\hline Figure & Procedure & RT enzyme & Priming method & PCR enzyme & $\begin{array}{l}\text { SIV } \\
\text { input } \\
\text { (copies) }\end{array}$ & $\begin{array}{l}\text { SIV } \\
\text { count } \\
\text { (copies) }\end{array}$ & PCR thermal cycling condition \\
\hline $1 \mathrm{~A}$ & \multirow[t]{8}{*}{ One step } & \multirow[t]{8}{*}{ SSIII } & \multirow[t]{8}{*}{ Gene-specific } & \multirow[t]{8}{*}{ Platinum Taq } & 0 & N.D & \multirow{8}{*}{$\begin{array}{l}50^{\circ} \mathrm{C} 30 \mathrm{~min}, 94^{\circ} \mathrm{C} 7 \mathrm{~min}, 38 \times\left(94^{\circ} \mathrm{C} 14 \mathrm{~s}, 60^{\circ} \mathrm{C} 30 \mathrm{~s},\right. \\
\left.68^{\circ} \mathrm{C} 30 \mathrm{~s}, 94^{\circ} \mathrm{C} 1 \mathrm{~s}\right), 94^{\circ} \mathrm{C} 14 \mathrm{~s}, 60^{\circ} \mathrm{C} 30 \mathrm{~s}, 68^{\circ} \mathrm{C} \\
5 \min 30 \mathrm{~s}, 98^{\circ} \mathrm{C} 10 \mathrm{~min}, 4^{\circ} \mathrm{C} \text { hold }\end{array}$} \\
\hline 1B & & & & & 10 & N.D & \\
\hline $1 C$ & & & & & 0 & N.D & \\
\hline $1 \mathrm{D}$ & & & & & 10 & N.D & \\
\hline $1 \mathrm{E}$ & & & & & 0 & N.D & \\
\hline $1 \mathrm{~F}$ & & & & & 10 & N.D & \\
\hline $1 \mathrm{G}$ & & & & & 0 & N.D & \\
\hline $1 \mathrm{H}$ & & & & & 10 & N.D & \\
\hline $2 \mathrm{~A}$ & \multirow[t]{8}{*}{ Two step } & \multirow[t]{2}{*}{ M-MLV } & \multirow[t]{4}{*}{ Gene-specific } & \multirow[t]{8}{*}{ AmpliTaq Gold } & 0 & 0 & $\begin{array}{l}\text { (RT) } 25^{\circ} \mathrm{C} 15 \mathrm{~min} ; 37^{\circ} \mathrm{C} 60 \mathrm{~min} ; 90^{\circ} \mathrm{C} 30 \mathrm{~min} ; 25^{\circ} \mathrm{C} \\
30 \mathrm{~min} ; 4^{\circ} \mathrm{C} \text { hold. (PCR) } 95^{\circ} \mathrm{C} 7 \mathrm{~min}, 40 \times\left(95^{\circ} \mathrm{C} 15 \mathrm{~s} \text {, }\right. \\
\left.60{ }^{\circ} \mathrm{C} 1 \mathrm{~min}\right), 98^{\circ} \mathrm{C} 10 \mathrm{~min}, 4^{\circ} \mathrm{C} \text { hold }\end{array}$ \\
\hline $2 \mathrm{~B}$ & & & & & 10 & 14 & \\
\hline $2 C$ & & \multirow[t]{2}{*}{ SSIII } & & & 0 & 1 & \multirow{2}{*}{$\begin{array}{l}\text { (RT) } 25^{\circ} \mathrm{C} 15 \text { min; } 37^{\circ} \mathrm{C} 60 \mathrm{~min} ; 85^{\circ} \mathrm{C} 5 \mathrm{~min} ; 25^{\circ} \mathrm{C} \\
30 \mathrm{~min} ; 4^{\circ} \mathrm{C} \text { hold. (PCR) } 95^{\circ} \mathrm{C} 7 \mathrm{~min}, 40 \times\left(95^{\circ} \mathrm{C} 15 \mathrm{~s} \text {, }\right. \\
\left.60{ }^{\circ} \mathrm{C} 1 \mathrm{~min}\right), 98^{\circ} \mathrm{C} 10 \mathrm{~min}, 4^{\circ} \mathrm{C} \text { hold }\end{array}$} \\
\hline $2 \mathrm{D}$ & & & & & 10 & 14 & \\
\hline $2 \mathrm{E}$ & & \multirow[t]{2}{*}{ M-MLV } & \multirow[t]{4}{*}{ Random hexamer } & & 0 & 0 & \multirow{2}{*}{$\begin{array}{l}\text { (RT) } 25^{\circ} \mathrm{C} 15 \mathrm{~min} ; 50^{\circ} \mathrm{C} 50 \mathrm{~min} ; 90^{\circ} \mathrm{C} 30 \mathrm{~min} ; 25^{\circ} \mathrm{C} \\
30 \mathrm{~min} ; 4^{\circ} \mathrm{C} \text { hold. (PCR) } 95^{\circ} \mathrm{C} 7 \mathrm{~min}, 40 \times\left(95^{\circ} \mathrm{C} 15 \mathrm{~s} \text {, }\right. \\
\left.60{ }^{\circ} \mathrm{C} 1 \mathrm{~min}\right), 98^{\circ} \mathrm{C} 10 \mathrm{~min}, 4^{\circ} \mathrm{C} \text { hold }\end{array}$} \\
\hline $2 \mathrm{~F}$ & & & & & 10 & 1 & \\
\hline $2 \mathrm{G}$ & & \multirow[t]{2}{*}{ SSIIII } & & & 0 & 1 & \multirow{2}{*}{$\begin{array}{l}\text { (RT) } 25^{\circ} \mathrm{C} 15 \mathrm{~min} ; 50^{\circ} \mathrm{C} 50 \mathrm{~min} ; 85^{\circ} \mathrm{C} 5 \mathrm{~min} ; 25^{\circ} \mathrm{C} \\
30 \mathrm{~min} ; 4^{\circ} \mathrm{C} \text { hold. (PCR) } 95^{\circ} \mathrm{C} 7 \mathrm{~min}, 40 \times\left(95^{\circ} \mathrm{C} 15 \mathrm{~s}\right. \\
\left.60^{\circ} \mathrm{C} 1 \mathrm{~min}\right), 98^{\circ} \mathrm{C} 10 \mathrm{~min}, 4^{\circ} \mathrm{C} \text { hold }\end{array}$} \\
\hline $2 \mathrm{H}$ & & & & & 10 & 2 & \\
\hline $3 \mathrm{~A}$ & \multirow[t]{4}{*}{ Two-step } & \multirow[t]{4}{*}{ SSIII } & \multirow[t]{2}{*}{ Gene-specific } & \multirow[t]{4}{*}{ AmpliTaq Gold } & 0 & N.D & \multirow{4}{*}{$\begin{array}{l}\text { (RT) } 25^{\circ} \mathrm{C} 15 \mathrm{~min} ; 50^{\circ} \mathrm{C} 50 \mathrm{~min} ; 85^{\circ} \mathrm{C} 5 \mathrm{~min} ; 25^{\circ} \mathrm{C} \\
30 \mathrm{~min} ; 4^{\circ} \mathrm{C} \text { hold. }(\mathrm{PCR}) 95^{\circ} \mathrm{C} 7 \mathrm{~min}, 40 \times\left(95^{\circ} \mathrm{C} 15 \mathrm{~s} \text {, }\right. \\
\left.60{ }^{\circ} \mathrm{C} 1 \mathrm{~min}\right), 98^{\circ} \mathrm{C} 10 \mathrm{~min}, 4^{\circ} \mathrm{C} \text { hold }\end{array}$} \\
\hline $3 B$ & & & & & 100 & N.D & \\
\hline $3 C$ & & & \multirow[t]{2}{*}{ Random hexamer } & & 0 & N.D & \\
\hline $3 \mathrm{D}$ & & & & & 100 & N.D & \\
\hline $4 \mathrm{~A}$ & \multirow[t]{2}{*}{ Two-step } & \multirow[t]{2}{*}{ SSIV } & \multirow[t]{2}{*}{ Gene-specific } & \multirow[t]{2}{*}{ AmpliTaq Gold } & 0 & 0 & \multirow{2}{*}{$\begin{array}{l}\text { (RT) } 25^{\circ} \mathrm{C} 15 \text { min; } 50^{\circ} \mathrm{C} 10 \text { min; } 95^{\circ} \mathrm{C} 10 \text { min; } 25^{\circ} \mathrm{C} \\
30 \mathrm{~min} ; 4^{\circ} \mathrm{C} \text { hold. (PCR) } 95^{\circ} \mathrm{C} 7 \text { min, } 40 \times\left(95^{\circ} \mathrm{C} 15 \mathrm{~s} \text {, }\right. \\
\left.60{ }^{\circ} \mathrm{C} 1 \mathrm{~min}\right), 98^{\circ} \mathrm{C} 10 \mathrm{~min}, 4^{\circ} \mathrm{C} \text { hold }\end{array}$} \\
\hline $4 \mathrm{~B}$ & & & & & 10 & 10 & \\
\hline
\end{tabular}

Reaction conditions (including the specific procedure applied (i.e. one-step vs. two-step RT-ddPCR), the reverse transcriptase (RT) enzyme used at the RT step, the priming method, the enzyme used at the ddPCR step, and the PCR thermal cycling condition) and quantification results (including SIV input (copies) and count (copies)) are listed. N.D., quantitation not done due to background signals

[22], making it ideally suited for applications involving detection of rare events such as required in many HIV reservoir/cure studies in which viral nucleic acid level is tremendously suppressed. This RT-ddPCR assay was also subjected to additional validation and testing [22]. The linear dynamic range of the assay was at least up to 1 million copies (test upper limit) of viral nucleic acid per reaction [22]. The lower limit of detection for the assay under the M-MLV and gene-specific priming combination condition was determined to be 7 copies per reaction, and the sensitivity and specificity of the assay were determined to be $93 \%$ and $100 \%$, respectively.

The reverse transcription step, in which RNA is converted to a DNA template by a reverse transcriptase, can potentially introduce variability and ambiguity through different factors (such as RNA quality and inhibitors) to the final quantitation data in RT-PCR procedures. Endogenous, copurified inhibitors and reagents introduced during sample procurement or extraction often present issues as they can inhibit the reverse transcription step, the PCR step, or both. We recently described using the SuperScript IV reverse transcriptase to overcome severe inhibition at the reverse transcription step. Combining this with Raindance ddPCR system at the PCR step could allow quantifying the SIV viral target in RNA samples that demonstrated more than $99.99 \%$ inhibition in qRTPCR procedure [22]. Therefore, combining a high processivity RT with Raindance ddPCR can potentially expand the repertoire of analyzable tissue RNA samples without the need to remove inhibitors, which is especially important in scenarios where the identity of the inhibitor is unknown.

Different priming methods at the reverse transcription step can lead to different cDNA yield and priming specificity. For example, random priming gives the highest cDNA yield due to the fact that priming initiates from multiple points along the template. However, the majority of cDNA generated through random priming will be 

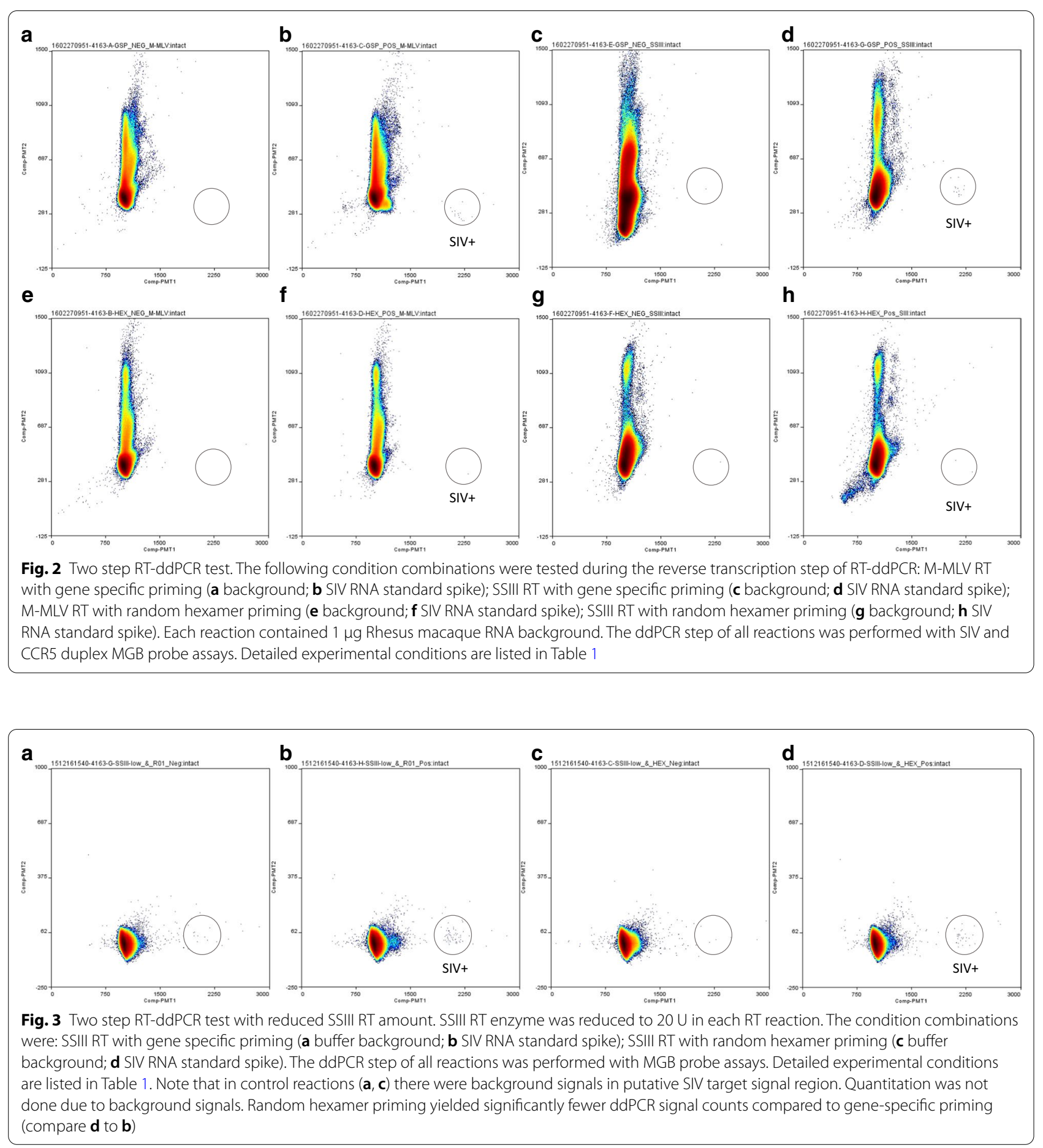

from ribosomal RNA and may compete with low level targets. Target/gene-specific priming leads to the most specific cDNA. Consistent with this, we observed that when gene-specific priming was used in the 2-step procedure, there was general agreement between the ddPCR reading and signal input, while random hexamer priming usually yielded significantly fewer ddPCR signal counts compared to template input. It therefore appears that for HIV cure/reservoir studies where the viral detection target signals are at low levels, gene-specific priming should be the preferred priming method during RT-ddPCR analysis. 

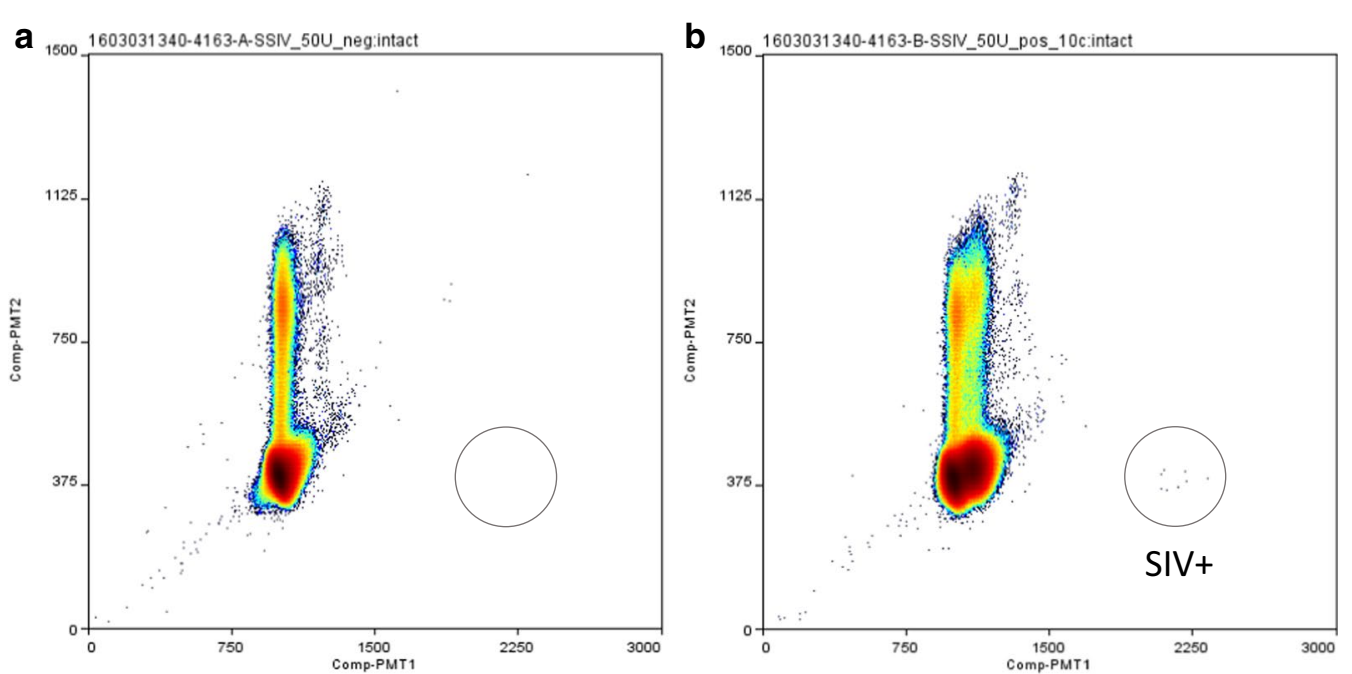

Fig. 4 SSIV test. The condition combination was SSIV with gene specific priming (a $1 \mu \mathrm{g}$ Rhesus macaque RNA background; b SIV RNA standard spiked in $1 \mu \mathrm{g}$ Rhesus macaque RNA background). The ddPCR step of both reactions was performed with MGB probe assays. Detailed experimental conditions are listed in Table 1

Quantitation of the SIV RNA reference standard used in this study was based on A260 measurements and the calculated extinction coefficient for the transcript sequence, and validation by terminal dilution qRT-PCR. In Fig. $2 b, d, f$ and $h, 10$ copies (based on prior quantification) of SIV RNA template were used as input in each reaction. Based on ddPCR results in Fig. $2 b$, $f$, the prior quantification under-quantifies the SIV RNA template by about $29 \%$ (10 copies vs. 14 copies), assuming the conditions in $2 \mathrm{~b}$ and $2 \mathrm{f}$ allow detecting all target signals present, although another possible contributing factor is the serial dilution step. This highlights the vulnerability of qRT-PCR analysis to inaccuracies introduced during steps such as the quantification and serial dilution of the external calibrator molecules. Nevertheless, valid comparisons can still be made regarding the relative performance of the assays under various RT-ddPCR conditions by comparing the ddPCR signal counts obtained under these conditions.

\section{Conclusions}

Combining gene-specific priming with suitable reverse transcriptases, and using the Raindance ddPCR platform at the signal detection step allowed development of a sensitive SIV RT-ddPCR assay that has many potential applications of interest to HIV reservoir/cure studies. Similar conditions can be explored on the Raindance ddPCR system to enable potential development and validation of additional assays for applications that require sensitive detection of low amount target(s).

\section{Methods}

RNA extraction and qPCR quantification of SIV viral RNA

RNA isolation and qRT-PCR quantification of tissuederived SIV RNA followed procedures and conditions as described previously [42-45] and are briefly described here.

Small specimens (i.e. cell pellets or tissue specimens of $\leq 200 \mathrm{mg}$ ) were homogenized in $1 \mathrm{~mL}$ of TriReagent (Molecular Research Center) in $2 \mathrm{~mL}$ homogenization tubes (P000918-LYSK0-A, Bertin Instruments) containing ceramic (zirconium oxide) beads as grinding material using a Precellys tissue homogenizer (Bertin Instruments) according to the reagent manufacturer's recommendations. Tissue specimens of $200 \mathrm{mg}$ to $2 \mathrm{~g}$ quantity range, or $400 \mathrm{mg}$ to $4 \mathrm{~g}$ quantity range, were processed in $7 \mathrm{~mL}$ (P000935-LYSK0-A, Bertin Instruments) or $15 \mathrm{~mL}$ (P000947-LYSK0-A, Bertin Instruments) homogenization tubes containing ceramic (zirconium oxide) beads as grinding material, respectively. For large tissue samples, total RNA was prepared from $1 \mathrm{~mL}$ of TriReagent suspension, with residual suspension being archived at $-80{ }^{\circ} \mathrm{C}$ for potential additional analysis. All ensuing procedures are based on $1 \mathrm{~mL}$ TriReagent homogenate.

RNA isolation from the homogenate included the following steps: (1) Phase separation. The homogenate was stored for $5 \mathrm{~min}$ at room temperature to allow complete dissociation of nucleoprotein complexes. The homogenate was spun at 13,000 $\mathrm{g}$ for $1 \mathrm{~min}$, and the top lipid layer removed with a pipette. For phase separation, $0.1 \mathrm{~mL}$ 1-bromo-3-chloropropane (BCP) was added to 
the homogenate. The sample was vortexed vigorously for $15 \mathrm{~s}$. The resulting mixture was incubated at room temperature for $15 \mathrm{~min}$ and centrifuged at 14,000 $\mathrm{g}$ for 15 min at $4{ }^{\circ} \mathrm{C}$. Following centrifugation, RNA remained exclusively in the colorless upper aqueous phase. (2) RNA precipitation and wash. The aqueous phase was transferred to a fresh tube containing $240 \mu \mathrm{g}$ glycogen (Roche 34990920). $0.5 \mathrm{~mL}$ of isopropanol was added to the aqueous phase. The mixture was vortexed for $5 \mathrm{~s}$, incubated at room temperature for 5-10 min then centrifuged at $21,000 \mathrm{~g}$ for $10 \mathrm{~min}$ at $25^{\circ} \mathrm{C}$. The supernatant was removed and the RNA pellet was washed by vortexing with $0.5 \mathrm{~mL}$ of $70 \%$ ethanol. The RNA pellet was stored at $-20{ }^{\circ} \mathrm{C}$ in ethanol overnight, and was washed a second time with $0.5 \mathrm{~mL} 70 \%$ ethanol. The ethanol wash was then decanted and the RNA pellet allowed to air-dry for $5 \mathrm{~min}$. Recovered RNA was dissolved in $240 \mu \mathrm{L}$ of $10 \mathrm{mM}$ Tris, pH 8.0 for replicate testing in qRT-PCR protocol.

For qRT-PCR quantification of SIV in tissue-derived RNA, reaction conditions and thermal profiles followed those for the plasma and isolated cell assays as described previously [43, 44] with two exceptions: (1) In the reverse transcription step, the 'nested' reverse primer (SIVnestR01) [46], as opposed to random hexamers, was used to prime cDNA synthesis specifically for SIV sequence to avoid generation of non-specific targets and enhance the sensitivity of detection of SIV; (2) 1.25 units of PlatinumTaq (Invitrogen), rather than TaqGold, were used in the amplification steps. For RNA determination, $12(10+2$ format $)$ or $6(5+1$ format $)$ replicate reactions were tested per sample including a spike of RNA internal control sequence standard [47] (1000 copies per reaction) in two of the 12 reactions $(10+2$ format) or one of the 6 reactions $(5+1$ format) to assess overall amplification efficiency and potential inhibition of the PCR.

\section{Reverse transcriptases}

Three reverse transcriptases were tested in this study. These include: (1) Moloney Murine Leukemia Virus Reverse Transcriptase (M-MLV) (28025013, ThermoFisher Scientific), a recombinant DNA polymerase that lacks DNA endonuclease activity and has a lower RNase $\mathrm{H}$ activity. M-MLV has an optimal activity at $37{ }^{\circ} \mathrm{C}$. (2) SuperScript III Reverse Transcriptase (SSIII) (18080093, ThermoFisher Scientific), generated by introducing several mutations into M-MLV to further reduce RNase $\mathrm{H}$ activity and increase half-life. SSIII has an optimal activity at $50{ }^{\circ} \mathrm{C}$. Compared to M-MLV, SuperScript III reverse transcriptase was found to produce higher cDNA yields, improved cDNA lengths and enhanced efficiency on GC-rich target RNAs. (3) SuperScript IV Reverse Transcriptase (SSIV) (18090010, ThermoFisher Scientific), an enzyme developed particularly for challenging samples such as poorly purified RNA that contains inhibitors, RNA from formalin-fixed, paraffinembedded (FFPE) samples, and unpurified RNA. The enzyme demonstrates low variability especially at low amount of input RNA and has the highest thermostability $\left(100 \%\right.$ activity up to $56{ }^{\circ} \mathrm{C}$ and $90 \%$ activity at $\left.60{ }^{\circ} \mathrm{C}\right)$ among the 3 reverse transcriptases.

\section{One-step RT-ddPCR}

For one-step RT-ddPCR, the following RT reaction was prepared in a volume of $50 \mu \mathrm{L}$ (all concentrations indicate final concentration): $25 \mu \mathrm{L}$ of $2 \times$ reaction buffer and $2 \mu \mathrm{L}$ of SuperScript III RT/Platinum Taq Mix from the SuperScript III One-Step RT-PCR System with Platinum Taq DNA Polymerase (12574018, ThermoFisher Scientific, Waltham, MA), SIVnestR01 (2 $\mu \mathrm{M})$, SGag ddPCR forward and reverse primers (600 nM each), SGag ddPCR probe $(200 \mathrm{nM})[22,48]$, RNA sample, reference standard or buffer, 1xddPCR stabilizer (Raindance) and $\mathrm{H} 2 \mathrm{O}$. For duplex SIV and CCR5 one-step RT-ddPCR, the mixture also contains RCCR5 forward and reverse primers (600 nM each) $[22,48]$ and RCCR5ProbeMGB (200 nM) $[22,48]$.

The mixture was then dropletized on Raindance source instrument according to the manufacturer's instructions. Droplet integrity was monitored by visually examining a portion of the droplets in each lane as they moved through the device during dropletization. Total droplet count data for each sample after dropletization was retrieved from the Source instrument as an independent measure of droplet generation success.

One step RT-ddPCR thermocycling was performed on a Bio-Rad C1000 Touch Thermal Cycler with the following PCR cycling conditions: $50{ }^{\circ} \mathrm{C} 30 \mathrm{~min}, 94{ }^{\circ} \mathrm{C} 7 \mathrm{~min}$ (these constitute the RT segments) followed by $38 \times$ $\left(94{ }^{\circ} \mathrm{C} 14 \mathrm{~s}, 60{ }^{\circ} \mathrm{C} 30 \mathrm{~s}, 68^{\circ} \mathrm{C} 30 \mathrm{~s}, 94{ }^{\circ} \mathrm{C} 1 \mathrm{~s}\right), 94{ }^{\circ} \mathrm{C} 14 \mathrm{~s}$, $60{ }^{\circ} \mathrm{C} 30 \mathrm{~s}, 68{ }^{\circ} \mathrm{C} 5 \mathrm{~min} 30 \mathrm{~s}, 98^{\circ} \mathrm{C} 10 \mathrm{~min}, 4^{\circ} \mathrm{C}$ hold.

After thermocycling, droplet fluorescence detection was performed on the RainDrop Sense instrument following the manufacturer's instruction. At the end of Sense instrument reading, total droplet count data for each sample was retrieved from the Sense instrument.

\section{Two-step RT-ddPCR}

The RT step of the two-step RT-ddPCR was performed in a total volume of $15 \mu \mathrm{L}$ composed of the following: $5 \mathrm{mM} \mathrm{MgCl}_{2}, 500 \mathrm{nM}$ of each dNTP, $1 \mathrm{mM}$ DTT, $2 \mu \mathrm{M}$ of SIVNestR01 [46] or $5 \mu \mathrm{g}$ random hexamers (ThermoFisher), $1 \times$ PCR II buffer (ThermoFisher) with $0.2 \%$ Tween, 10 U RNaseOUT, M-MLV, SSIII or SSIV (ThermoFisher) reverse transcriptase (amount varies), RNA sample (or reference standard or buffer) and $\mathrm{H}_{2} \mathrm{O}$. The PCR thermocycling programs for the RT step are: For 
M-MLV: $25^{\circ} \mathrm{C} 15 \mathrm{~min} ; 37^{\circ} \mathrm{C} 60 \mathrm{~min} ; 90{ }^{\circ} \mathrm{C} 30 \mathrm{~min} ; 25^{\circ} \mathrm{C}$ $30 \mathrm{~min} ; 4^{\circ} \mathrm{C}$ hold. For SSIII: $25^{\circ} \mathrm{C} 15 \mathrm{~min} ; 50{ }^{\circ} \mathrm{C} 50 \mathrm{~min}$; $85{ }^{\circ} \mathrm{C} 5 \mathrm{~min} ; 25^{\circ} \mathrm{C} 30 \mathrm{~min} ; 4{ }^{\circ} \mathrm{C}$ hold. For SSIV, $25^{\circ} \mathrm{C}$ 15 min; $50{ }^{\circ} \mathrm{C} 10 \mathrm{~min} ; 95{ }^{\circ} \mathrm{C} 10 \mathrm{~min} ; 25{ }^{\circ} \mathrm{C} 30 \mathrm{~min} ; 4{ }^{\circ} \mathrm{C}$ hold.

After the RT step, the reverse transcription product was directly combined with the following reagents to yield a total mixture volume of $50 \mu \mathrm{L}$ (the following are final concentrations of reagents in the ddPCR reaction): $1 \times$ TaqMan genotyping mastermix, SGag ddPCR forward and reverse primers (600 nM each), SGag ddPCR probe $(200 \mathrm{nM}), 1 \times$ reaction stabilizer (RainDance) and water. In duplex SIV/RCCR5 RT-ddPCR, RCCR5 ddPCR forward and reverse primers (600 $\mathrm{nM}$ each) and RCCR5 ddPCR probe (200 nM) were also included in the mixture.

Dropletization was performed on the Raindance sense instrument according to the manufacturer's instructions and as described above. End-point PCR thermocycling was performed on a Bio-Rad C1000 Touch Thermal Cycler with the following PCR cycling conditions: $95{ }^{\circ} \mathrm{C}$ $7 \mathrm{~min} ; 40$ cycles of $\left(95^{\circ} \mathrm{C}, 15 \mathrm{~s} ; 60^{\circ} \mathrm{C}, 1 \mathrm{~min}\right.$ with a ramp rate of $\left.0.5{ }^{\circ} \mathrm{C} / \mathrm{s}\right) ; 98{ }^{\circ} \mathrm{C} 10 \mathrm{~min} ; 4^{\circ} \mathrm{C}$ hold. Sense reading and data analysis were performed as described above.

\section{ddPCR data analysis}

Data from Sense runs were analyzed using RainDrop Analyst software to calculate the template copy number by modeling as a Poisson distribution. The formula used for singleplex Poisson modeling was:

$$
\text { Copies per droplet }=-\ln (1-p)
$$

where $\mathrm{p}=$ fraction of positive droplets.

For duplex assay Poisson modeling, the following definition and formula were used:

$$
\begin{aligned}
& A^{-} B^{-}=N \times e^{-A \%} \times e^{-B \%} \\
& A^{+} B^{+}=N \times\left(1-e^{-A \%}\right) \times\left(1-e^{-B \%}\right) \\
& A^{+} B^{-}=N \times\left(1-e^{-A \%}\right) \times e^{-B \%} \\
& A^{-} B^{+}=N \times e^{-A \%} \times\left(1-e^{-B \%}\right) \\
& A \%=-\ln \frac{1+\frac{A^{-} B^{+}-A^{+} B^{-}}{N}+\sqrt{\left(1+\frac{A^{-} B^{+}-A^{+} B^{-}}{N}\right)^{2}-\frac{4 A^{-} B^{+}}{N}}}{2} \\
& B \%=-\ln \frac{1+\frac{A^{+} B^{-}-A^{-} B^{+}}{N}+\sqrt{\left(1+\frac{A^{+} B^{-}-A^{-} B^{+}}{N}\right)^{2}-\frac{4 A^{+} B^{-}}{N}}}{2}
\end{aligned}
$$

where $\mathrm{A}^{-} \mathrm{B}^{-}$refers to the number of droplets that contain neither target, $\mathrm{A}^{-} \mathrm{B}^{+}$refers to the number of droplets that contain target $\mathrm{B}$ only, $\mathrm{A}^{+} \mathrm{B}^{-}$refers to the number of droplets that contain target $\mathrm{A}$ only, and $\mathrm{A}^{+}$ $\mathrm{B}^{+}$refers to the number of droplets that contain both targets. $\mathrm{N}=$ total number of droplet events.

\section{Supplementary Information}

The online version contains supplementary material available at https://doi. org/10.1186/s12985-021-01503-5.

Additional file 1. Supplementary Figure 1. Two step RT-ddPCR test with M-MLV RT. M-MLV RT with gene specific priming condition combination was tested during the reverse transcription step of RT-ddPCR (A: buffer background; B: SIV RNA standard spike). The ddPCR step of both reactions was performed with MGB probe assays. Detailed experimental conditions are listed in Supplementary Table 1. Supplementary Table 1. RT-ddPCR reaction condition and quantification results. Reaction conditions (including the specific procedure applied (i.e. two-step RT-ddPCR), the reverse transcriptase (RT) enzyme used at the RT step, the priming method, the enzyme used at the $\mathrm{ddPCR}$ step, and the PCR thermal cycling condition) and quantification results (including SIV input (copies) and count (copies)) are listed.

\section{Abbreviations}

AAALAC: American Association for Accreditation of Laboratory Animal Care; CNV: Copy number variation; Ct: Threshold cycle; ddPCR: Droplet digital PCR; RT: Reverse transcriptase; FFPE: Formalin-fixed, paraffin-embedded; GMO: Genetically modified organism; HIV: Human immunodeficiency virus; HTLV: Human T-cell leukaemia virus; MGB: Minor groove binder; miRNA: MicroRNA; M-MLV: Moloney Murine Leukemia Virus Reverse Transcriptase; NGS: Next generation sequencing; qPCR: Quantitative (real-time) PCR; qRT-PCR: Quantitative reverse transcription PCR; RT-ddPCR: Reverse transcription droplet digital PCR; SARS-CoV-2: Severe acute respiratory syndrome coronavirus 2; SIV: Simian immunodeficiency virus; SSIII: SuperScript III reverse transcriptase; SSIV: SuperScript IV reverse transcriptase.

\section{Acknowledgements}

The authors would like to acknowledge Drs. Jeffrey Lifson and Robert Gorelick for valuable comments on the manuscript. 


\section{Authors' contributions}

SL designed the study. SL and BB collected and analyzed the data. SL interpreted the data and wrote the manuscript. Both authors read and approved the final manuscript.

\section{Funding}

Open Access funding provided by the National Institutes of Health (NIH). This project has been funded with Federal funds from the National Cancer Institute, National Institutes of Health, under contract numbers HHSN261200800001E and 75N91019D00024. The content of this publication does not necessarily reflect the views or policies of the Department of Health and Human Services, nor does mention of trade names, commercial products, or organizations imply endorsement by the US Government.

\section{Availability of data and materials}

All data generated or analysed during this study are included in this published article and its supplementary information files.

\section{Ethics approval and consent to participate}

Rhesus macaques (Macaca mulatta) were housed and cared for in compliance with American Association for Accreditation of Laboratory Animal Care (AAALAC) guidelines in an AAALAC-accredited facility, and all animal procedures were performed in accordance with protocols approved by the Institutional Animal Care and Use Committee of the National Cancer Institute under the standards of the NIH guide for the Care and Use of Laboratory Animals.

\section{Consent for publication}

Not applicable.

\section{Competing interests}

The authors declare that they have no competing interests.

Received: 29 December 2020 Accepted: 1 February 2021

Published online: 15 February 2021

\section{References}

1. Policicchio BB, Cardozo EF, Sette P, Xu C, Haret-Richter G, Dunsmore T, et al. Dynamics of simian immunodeficiency virus two-long-terminalrepeat circles in the presence and absence of CD8+ cells. J Virol. 2018:92:e02100-17.

2. Birkenheuer CH, Danko CG, Baines JD. Herpes simplex virus 1 dramatically alters loading and positioning of rna polymerase ii on host genes early in infection. J Virol. 2018;92:e02184-17.

3. Sherman KE, Rouster SD, Kong LX, Aliota MT, Blackard JT, Dean GE. Zika virus replication and cytopathic effects in liver cells. PLOS ONE. 2019;14:e0214016.

4. Schutten M, Niesters HG. Clinical utility of viral quantification as a tool for disease monitoring. Expert Rev Mol Diagn. 2001;1:153-62.

5. Mackay IM, Arden KE, Nitsche A. Real-time PCR in virology. Nucleic Acids Res. 2002;30:1292-305.

6. Syrmis MW, Whiley DM, Thomas M, Mackay IM, Williamson J, Siebert $D J$, et al. A sensitive, specific, and cost-effective multiplex reverse transcriptase-PCR assay for the detection of seven common respiratory viruses in respiratory samples. J Mol Diagn. 2004;6:125-31.

7. Stone B, Burrows J, Schepetiuk S, Higgins G, Hampson A, Shaw R, et al. Rapid detection and simultaneous subtype differentiation of influenza $A$ viruses by real time PCR. J Virol Methods. 2004;117:103-12.

8. Verstrepen WA, Kuhn S, Kockx MM, Van De Vyvere ME, Mertens AH. Rapid detection of enterovirus RNA in cerebrospinal fluid specimens with a novel single-tube real-time reverse transcription-PCR assay. J Clin Microbiol. 2001;39:4093-6.

9. Corman VM, Landt O, Kaiser M, Molenkamp R, Meijer A, Chu DK. Detection of 2019 novel coronavirus (2019-nCoV) by real-time RT-PCR. Euro Surveill. 2020;25:2000045.

10. CDC (Centers for Disease Control and Prevention). Coronavirus Disease 2019 (COVID-19). 2020. https://www.cdc.gov/coronavirus/2019-ncov/lab/ rt-pcr-panel-primer-probes.html. Accessed 15 Oct 2020.

11. Schwarz BA, Bange R, Vahlenkamp TW, Johne R, Muller H. Detection and quantitation of group $A$ rotaviruses by competitive and real-time reverse transcription-polymerase chain reaction. J Virol Methods. 2002;105:277-85.

12. Jagodzinski LL, Manak MM, Hack HR, Liu Y, Peel SA. Performance evaluation of a laboratory developed PCR test for quantitation of HIV-2 viral RNA. PLOS ONE. 2020;15:e0229424.

13. Whitmill A, Kim S, Rojas V, Gulraiz F, Afreen K, Jain M, et al. Signature molecules expressed differentially in a liver disease stage-specific manner by HIV-1 and HCV co-infection. PLoS ONE. 2018;13:e0202524.

14. Calascibetta F, Micci L, Carnathan D, Lawson B, Vanderford TH, Bosinger SE, et al. Antiretroviral therapy in simian immunodeficiency virusinfected sooty mangabeys: implications for AIDS pathogenesis. J Virol. 2016:90:7541-51.

15. Palmer S, Wiegand AP, Maldarelli F, Bazmi H, Mican JM, Polis M, et al. New real-time reverse transcriptase-initiated PCR assay with single-copy sensitivity for human immunodeficiency virus type 1 RNA in plasma. J Clin Microbiol. 2003:41:4531-6.

16. Williams JP, Hurst J, Stöhr W, Robinson N, Brown H, Fisher M, et al. HIV-1 DNA predicts disease progression and post-treatment virological control. Elife. 2014;3:e03821.

17. Verstrepen WA, Bruynseels P, Mertens AH. Evaluation of a rapid real-time RT-PCR assay for detection of enterovirus RNA in cerebrospinal fluid specimens. J Clin Virol. 2002;25(Suppl 1):S39-43.

18. Drosten C, Günther S, Preiser W, van der Werf S, Brodt HR, Becker S, et al. Identification of a novel coronavirus in patients with severe acute respiratory syndrome. N Engl J Med. 2003;348:1967-76.

19. WHO (World Health Organization). Coronavirus disease (COVID-19) technical guidance: Laboratory testing for 2019-nCoV in humans. 2020. https ://www.who.int/emergencies/diseases/novel-coronavirus-2019/techn ical-guidance-publications. Accessed 15 Oct 2020.

20. Pasternak AO, Grijsen ML, Wit FW, Bakker M, Jurriaans S, Prins JM, et al. Cell-associated HIV-1 RNA predicts viral rebound and disease progression after discontinuation of temporary early ART. JCI Insight. 2020;5:e134196.

21. Whale AS, Huggett JF, Tzonev S. Fundamentals of multiplexing with digital PCR. Biomol Detect Quantif. 2016;10:15-23.

22. Long S, Berkemeier B. Maximizing viral detection with SIV droplet digital PCR (ddPCR) assays. PLoS ONE. 2020a;15(5):e0233085.

23. Pieknik JR, Bertke AS, Krause PR. Herpes simplex virus 2 in autonomic ganglia: evidence for spontaneous reactivation. J Virol. 2019:93:e00227-e319.

24. Brait M, Izumchenko E, Kagohara LT, Long S, Wysocki PT, Faherty B, et al. Comparative mutational landscape analysis of patient-derived tumour xenografts. Br J Cancer. 2017;116:515-23.

25. Openshaw MR, Mohamed AA, Ottolini B, Fernandez-Garcia D, Richards CJ, Page K, et al. Longitudinal monitoring of circulating tumour DNA improves prognostication and relapse detection in gastroesophageal adenocarcinoma. Br J Cancer. 2020. https://doi.org/10.1038/s4141 6-020-1002-8.

26. Zulato E, Attili I, Pavan A, Nardo G, Del Bianco P, Boscolo Bragadin A, et al. Early assessment of KRAS mutation in cfDNA correlates with risk of progression and death in advanced non-small-cell lung cancer. Br J Cancer. 2020;123:81-91.

27. Del Re M, Bordi P, Rofi E, Restante G, Valleggi S, Minari R, et al. The amount of activating EGFR mutations in circulating cell-free DNA is a marker to monitor osimertinib response. Br J Cancer. 2018;119:1252-8.

28. Rosa SF, Gatto F, Angers-Loustau A, Petrillo M, Kreysa J, Querci M. Development and applicability of a ready-to-use PCR system for GMO screening. Food Chem. 2016;201:110-9.

29. Dickinson KK, Hammond LC, Karner CM, Hastie ND, Carroll TJ, Goodyer P. Molecular determinants of WNT9b responsiveness in nephron progenitor cells. PLOS ONE. 2019;14:e0215139.

30. Monico J, Miller B, Rezeanu L, May W, Sullivan DC. Fibroblast growth factor receptor 1 amplification in laryngeal squamous cell carcinoma. PLoS ONE. 2018;13:e0186185.

31. Weaver S, Dube S, Mir A, Qin J, Sun G, Ramakrishnan R, et al. Taking qPCR to a higher level: analysis of CNV reveals the power of high throughput qPCR to enhance quantitative resolution. Methods. 2010;50:271-6.

32. Hellwig S, Nix DA, Gligorich KM, O'Shea JM, Thomas A, Fuertes CL, et al. Automated size selection for short cell-free DNA fragments enriches 
for circulating tumor DNA and improves error correction during next generation sequencing. PLoS ONE. 2018;13:e0197333.

33. Demeke T, Dobnik D. Critical assessment of digital PCR for the detection and quantification of genetically modified organisms. Anal Bioanal Chem. 2018:410:4039-50.

34. Strain MC, Lada SM, Luong T, Rought SE, Gianella S, Terry H, et al. Highly precise measurement of HIV DNA by droplet digital PCR. PLoS ONE. 2013;8:e55943.

35. Henderson LJ, Reoma LB, Kovacs JA, Nath A. Advances toward curing HIV-1 infection in tissue reservoirs. J Virol. 2020;94:e00375-e419.

36. Shen A, Zink MC, Mankowski JL, Chadwick K, Margolick JB, Carruth LM, et al. Resting CD4+ T lymphocytes but not thymocytes provide a latent viral reservoir in a simian immunodeficiency virus-Macaca nemestrina model of human immunodeficiency virus type 1-infected patients on highly active antiretroviral therapy. J Virol. 2003;77:4938-49.

37. Dinoso JB, Rabi SA, Blankson JN, Gama L, Mankowski JL, Siliciano RF, et al. A simian immunodeficiency virus-infected macaque model to study viral reservoirs that persist during highly active antiretroviral therapy. J Virol. 2009;83:9247-57.

38. Whitney JB, Hill AL, Sanisetty S, Penaloza-MacMaster P, Liu J, Shetty M, et al. Rapid seeding of the viral reservoir prior to SIV viraemia in rhesus monkeys. Nature. 2014;512:74-7.

39. Borducchi EN, Cabral C, Stephenson KE, Liu J, Abbink P, Ng'ang'a D, et al. Ad26/MVA therapeutic vaccination with TLR7 stimulation in SIV-infected rhesus monkeys. Nature. 2016;2016(540):284-7.

40. Krakoff E, Gagne RB, VandeWoude S, Carver S. Variation in intra-individual lentiviral evolution rates: a systematic review of human, nonhuman primate, and felid species. J Virol. 2019;93:e00538-e619.

41. Long S, Fennessey CM, Newman L, Reid C, O'Brien SP, Li Y, et al. Evaluating the intactness of persistent viral genomes in simian immunodeficiency virus-infected rhesus macaques after initiating antiretroviral therapy within one year of infection. J Virol. 2019;94:e01308-e1319.
42. Cline AN, Bess JW, Piatak M, Lifson JD. Highly sensitive SIV plasma viral load assay: practical considerations, realistic performance expectations, and application to reverse engineering of vaccines for AIDS. J Med Primatol. 2005;34:303-12.

43. Venneti S, Bonneh-Barkay D, Lopresti BJ, Bissel SJ, Wang G, Mathis CA, et al. Longitudinal in vivo positron emission tomography imaging of infected and activated brain macrophages in a macaque model of human immunodeficiency virus encephalitis correlates with central and peripheral markers of encephalitis and areas of synaptic degeneration. Am J Pathol. 2008;172:1603-16.

44. Hansen SG, Piatak M, Ventura AB, Hughes CM, Gilbride RM, Ford JC, et al. Immune clearance of highly pathogenic SIV infection. Nature. 2013:502:100-4.

45. Lindner L, Cayrou P, Jacquot S, Birling MC, Herault Y, Pavlovic G. Reliable and robust droplet digital PCR (ddPCR) and RT-ddPCR protocols for mouse studies. Methods. 2020. https://doi.org/10.1016/j.ymeth 2020.07.004.

46. Hansen SG, Ford JC, Lewis MS, Ventura AB, Hughes CM, Coyne-Johnson $L$, et al. Profound early control of highly pathogenic SIV by an effector memory T-cell vaccine. Nature. 2011;473:523-7.

47. Lifson JD, Rossio JL, Piatak M Jr, Parks T, Li L, Kiser R, et al. Role of CD8(+) lymphocytes in control of simian immunodeficiency virus infection and resistance to rechallenge after transient early antiretroviral treatment. J Virol. 2001;75:10187-99.

48. Long S, Berkemeier B. Development and optimization of a simian immunodeficiency virus (SIV) droplet digital PCR (ddPCR) assay. PLoS ONE. 2020b;15(10):e0240447.

\section{Publisher's Note}

Springer Nature remains neutral with regard to jurisdictional claims in published maps and institutional affiliations.
Ready to submit your research? Choose BMC and benefit from:

- fast, convenient online submission

- thorough peer review by experienced researchers in your field

- rapid publication on acceptance

- support for research data, including large and complex data types

- gold Open Access which fosters wider collaboration and increased citations

- maximum visibility for your research: over $100 \mathrm{M}$ website views per year

At BMC, research is always in progress.

Learn more biomedcentral.com/submissions 